\title{
Seasonal variability of the dynamics of dimethylated sulfur compounds in a coastal northwest Mediterranean site
}

\author{
Maria Vila-Costa ${ }^{1}$ \\ Institut de Ciències del Mar (CSIC), Passeig Marítim de la Barceloneta 37-49, 08003 Barcelona, Catalonia, Spain
}

\section{Ronald P. Kiene}

Department of Marine Sciences, University of South Alabama, Mobile, Alabama 36688

\section{Rafel Simó 2}

Institut de Ciències del Mar (CSIC), Passeig Marítim de la Barceloneta 37-49, 08003 Barcelona, Catalonia, Spain

\begin{abstract}
We studied the seasonal variation of biotic and abiotic processes and the physico-chemical forcing factors involved in the production and consumption of dimethylsulfide (DMS) and its precursor dimethylsulfoniopropionate (DMSP) at a coastal sampling station in the northwestern Mediterranean. Monthly samplings of surface seawater for an 18-month period revealed that algal-associated DMSP and dimethylsulfoxide (DMSO) did not follow total phytoplankton biomass (measured as chlorophyll $a$ [Chl $a]$ ). DMSP concentrations peaked 1 or 2 months later than the late winter $\mathrm{Chl} a$ bloom, following phytoplankton succession, whereas particulate DMSO was maximal in summer. Both Chl $a$-normalized concentrations (DMSP:Chl $a$ and DMSO : Chl $a$ ) exhibited a clear seasonality with maxima in summer, which was indicative of concurrent phytoplankton succession and physiological acclimation toward higher dimethylated sulfur-producing taxa in summer. DMS concentrations also showed clear maxima in mid-summer and minima in winter, which is anticorrelated with Chl $a$. Gross DMS production rates were higher in summer, coinciding with higher DMSP-to-DMS conversion yields and exceeded microbial DMS consumption in this season. Heterotrophic bacteria and DMSP-assimilating phytoplankton only accounted for a portion (annual average 52\%) of total DMSP transformations, suggesting that phytoplankton DMSP-lyases, either in stressed cells or upon grazing by herbivores, must play a more important role in DMS production than is generally believed. Calculated photolysis and measured microbial consumption alternated in dominance as DMS sinks over the year, with ventilation to the atmosphere generally being a minor loss process. Under higher solar radiation (from March to September), calculated photolysis followed variations of colored dissolved organic matter, a known DMS photosensitizer.
\end{abstract}

The biogenic gas dimethylsulfide (DMS) is the key compound that transfers sulfur from oceans to land through the atmosphere. It is, by far, the most abundant form in which the oceans exhale volatile sulfur. In the

\footnotetext{
${ }^{1}$ Current address: University of Georgia, Department of Marine Sciences, Athens, Georgia 30602-3636.

2 Corresponding author (rsimo@icm.csic.es).

Acknowledgments

We are grateful to F. Unrein and A. Gutiérrez for sharing light and pigment data, respectively, and to J.M. Gasol and the Blanes Bay Microbial Observatory study team for sampling assistance and coordination, and for providing nitrate and chlorophyll concentrations. G. Solduga assisted with cDOM measurements, and E. Blanch helped with meteorological data. We also thank two anonymous reviewers for their constructive comments that helped improve the manuscript.

This work was supported by the Spanish Ministry of Education and Science through a $\mathrm{PhD}$ studentship to M.V.-C., and through the projects MicroDiFF and MODIVUS (contracts REN20012120/MAR and CTM2005-04795/MAR to J.M.Gasol), by the Catalan government through grant 2005SGR00021 (to R.S.), and by the EU's 5th Framework Program through project BASICS (contract EVK3-CT-2002-00078 to J.M.G.). Additional support for R.P.K. was provided by a grant from the US National Science Foundation (OPP-0083078). This is a contribution to the objectives of the international program SOLAS and the Network of Excellence EUR-OCEANS of the EU's 6th Framework Program.
}

atmosphere, DMS oxidizes to form sulfate aerosols that scatter solar radiation and act as cloud condensation nuclei, thereby potentially increasing cloud albedo and influencing the radiation balance of the earth (Charlson et al. 1987). Despite its global-scale effects, the emission of DMS only represents a small percentage of total DMS produced in the surface ocean (Simó 2001). DMS ventilation is controlled by the transfer velocity (temperature and wind-speed dependent) as well as by the seasurface DMS concentration. Seasonal field studies and data compilations have shown that DMS tends to accumulate in summer months (e.g., Bates et al. 1987; Simó and PedrósAlió 1999a; Uher et al. 2000; Vallina and Simó 2007), and at mid-to-low latitudes (Dacey et al. 1998) it even reaches its maximum concentrations 2 months later than its precursor, dimethylsulfoniopropionate (DMSP), a compatible solute produced by a variety of species of phytoplankton (Keller et al. 1989). Its maximum concentrations coincide with a minimum of surface chlorophyll concentrations. The causes of this "DMS summer paradox" (Simó and Pedrós-Alió 1999a) still remain unresolved, and they can only be explained with a better understanding of the couplings and decouplings of the biological, chemical, and physical processes involved in DMS cycling and how they vary over an annual basis.

The DMS concentration in the upper ocean is controlled by a complex balance between production and loss 
processes (Simó 2001). DMS is produced from enzymatic cleavage of DMSP either from the dissolved pool (DMSPd) in bulk seawater or directly from the particulate pool (DMSPp) via bacterial or algal lyases, respectively (Stefels 2000; Yoch 2002). Intracellular DMSP is released into seawater through algal cell lysis caused by grazing, viral attack or autolysis, or exudation (Stefels 2000; Simó 2001). Transformations of DMSPd are carried out mainly by microorganisms (mainly heterotrophic bacteria but also non-DMSP-producing phytoplankton and phytoplankton possessing extracellular DMSP-lyases [Stefels and van Boekel 1993; Vila-Costa et al. 2006]) and result in high DMSPd turnover rates in many oceanic waters (Kiene et al. 2000).

The fate of DMSP degraded by bacteria is largely determined by the relative dominance of either a cleavage degradation pathway that converts DMSP into volatile DMS, or a demethylation pathway that produces mainly non-volatile sulfur products and fuels sulfur demands of heterotrophic bacteria (Kiene et al. 2000). Whereas the demethylation pathway (non-DMS-producing) appears to dominate dissolved DMSP degradation in most marine waters (Kiene and Linn 2000), considerable uncertainty remains regarding the factors that control the relative dominance of these two pathways and the contribution of bacterial transformations to total DMSP transformations and gross DMS production.

DMS is produced from the particulate DMSP pool either by DMSP-producers themselves (i.e., phytoplankton) or by action of zooplankton feeding on DMSPcontaining preys. The factors that control these phyto- and zooplankton-mediated transformations are of different nature. Intracellular DMSP cleavage and DMS release by phytoplankton are suggested to occur under oxidative stress conditions provoked by high ultraviolet (UV) radiation or nutrient limitation (Sunda et al. 2002). Grazing by meso- and microzooplankton gives rise to DMS either by action of algal DMSP lyases upon cell rupture (Dacey and Wakeham 1986; Wolfe and Steinke 1996) or by action of bacterial DMSP lyases in the guts and vacuoles of the grazer as DMSP-containing algal cells are digested (Tang et al. 2001; Archer et al. 2003). The relative importance of bacterioplankton, phytoplankton, and zooplankton-mediated DMSP transformations and DMS production has never been fully quantified, and it has been estimated in only two works (Burkill et al. 2002; Simó et al. 2002).

There are three main processes for DMS removal: microbial consumption, photooxidation, and ventilation to the atmosphere. Short-term studies in open-ocean waters have shown that the dominance of these removal pathways depends on physical forces (Simó and Pedrós-Alió 1999b). Microbial DMS consumption is inhibited by UV radiation (Slezak et al. 2001; Toole et al. 2006), and it is probably affected by other factors that regulate general bacterial activity, such as temperature or dissolved organic matter availability. DMS photooxidation occurs through secondary photosensitizers such as colored dissolved organic matter (cDOM) and nitrate, and it is dependent on incident solar radiation and sea-surface temperature (Toole et al.
2003; Toole et al. 2004). Ventilation depends mainly on wind speed and temperature (Nightingale et al. 2000).

Despite the phytoplankton origin of DMSP, DMS concentrations generally do not correlate with chlorophyll $a(\mathrm{Chl} a)$ concentrations either at regional to global scales (Kettle et al. 1999) or in seasonal studies (Leck et al. 1990; Turner et al. 1996; Dacey et al. 1998). This is mainly because of the taxon-specificity and physiological functionality of DMSP production (Keller et al. 1989; Stefels 2000) and to the non-straightforward conversion of DMSP into DMS. In non-bloom situations, DMS concentration seems to be mostly modulated by physical forces (Simó 2004; Toole and Siegel 2004; Vallina and Simó 2007). Two physical parameters largely explain DMS variability in oceanic surface waters: the depth of the mixing layer (Simó and Pedrós-Alió 1999a) and the UV radiation dose (Toole and Siegel 2004). Experimental evidence indicates that both parameters work together to have the same regulatory effect: in highly irradiated waters typical of summer conditions, stronger stratification of the water column favors high DMSP-producing phytoplankton, and high UV irradiances in shallow mixed layers generate high UV radiation (UVR) doses for plankton that may inhibit the consumption of DMSP and DMS by non-pigmented bacteria and enhance the anti-oxidative responses of phytoplankton, all resulting in higher DMS production than consumption (Slezak et al. 2001; Sunda et al. 2002; Simó 2004; Toole and Siegel 2004). Unfortunately, no field studies of the seasonal variation of each of these biological and physical factors and how they affect the DMSP and DMS dynamics have been conducted so far. We therefore undertook a study where we measured not only the major pools of dimethylated sulfur (DMS, DMSP, dimethylsulfoxide [DMSO]) but also the variation of biological processes (total DMSP consumption by the total community and dissolved DMSP consumption, specifically, DMS consumption, DMS production, DMSP-to-DMS conversion) and the variation of important DMS-driving physicochemical parameters (solar radiation, cDOM concentrations, nitrate concentrations, wind speed) over an annual cycle. The aim was to obtain a better understanding of the biogeochemical sulfur cycle in the surface ocean and to identify the key parameters needed to model its dynamics.

\section{Materials and methods}

Sampling-We sampled two consecutive days every month, from 13 January 2003 to 28 June 2004, in the Blanes Bay Microbial Observatory, NW Mediterranean, $41^{\circ} 40^{\prime} \mathrm{N}, 2^{\circ} 48^{\prime} \mathrm{E}$. Surface seawater was collected from a boat approximately $1 \mathrm{~km}$ offshore by submerging acidrinsed dark glass bottles to a depth of $0.5 \mathrm{~m}$ avoiding bubbling. Bottles (2.5 liter) were kept in the dark at in situ temperature until processing in Barcelona (usually $2 \mathrm{~h}$ after collection).

Basic data-Surface-water temperature was measured in situ with a thermometer. Temperature profiles were determined using a Niskin bottle to collect water from different fixed depths $(0,5,10,15,20 \mathrm{~m})$ plus closer 
additional depths when an increment of $1{ }^{\circ} \mathrm{C}$ was found. Mixing layer depths (MLDs) were determined as the shallowest depth with a $\Delta \mathrm{T} \geq 0.2^{\circ} \mathrm{C}$ from surface temperature. Chl $a$ was measured by fluorometry (Turner Designs fluorometer) after filtering $150 \mathrm{~mL}$ through glass fiber filters (GF/F; Whatman) and extracting with $90 \%$ acetone for $24 \mathrm{~h}$. Concentration of $\mathrm{NO}_{3}^{-}$was determined spectrophotometrically using an Alliance Evolution II autoanalyzer following standard procedures. Pyranometer surface solar irradiances were obtained from the meteorological station of Malgrat, located $4.5 \mathrm{~km}$ south of Blanes Bay. The light extinction coefficient $(\mathrm{k})$ was determined from photosynthetically active radiation (PAR) profiles using a Li-Cor radiometer. Daily ML-averaged solar radiation $\left(S R A D_{M L}\right)$ was calculated assuming an exponential decay of the daily-averaged surface solar irradiance $\left(S R A D_{0}\right)$ with depth following the equation (Vallina and Simó 2007)

$$
S R A D_{M L}=\left(S R A D_{0} /(k \times M L D)\right) \times\left(1-e^{(-k \times M L D)}\right)
$$

Analysis of sulfur compounds - Surface seawater concentrations of DMS, DMSP, and DMSO were determined following procedures described by Simó et al. (1996) and Simó and Vila-Costa (2006) using purging, cryotrapping, and sulfur-specific gas chromatography. The three compounds were measured sequentially: after sparging for endogenous DMS, DMSP was converted into DMS by alkaline hydrolysis; after second sparging, the sample was neutralized and DMSO was reduced to DMS with a combination of $\mathrm{NaBH}_{4}$ and $\mathrm{HCl}$. DMSO measurements were modified in the second part of this seasonal study (from September 2003 on). Briefly, after DMSP analysis, we added one-quarter of a cobalt-doped $\mathrm{NaBH}_{4}$ pellet (98\%, Aldrich Chemical) with no need for $\mathrm{pH}$ neutralization or acid addition. The same analytical precision was observed between both methods. The detection limit of the system was approximately $3 \mathrm{pmol} \mathrm{S}$. The precision (\%SE) of triplicate measurements was typically $\sim 2 \%$ for DMS and total DMSP (DMSPt), $\sim 10 \%$ for DMSPd, and $\sim 8 \%$ for DMSO measurements. DMSPt and total DMSO (DMSOt) concentrations were measured in non-filtered 20-50 mL-sample aliquots. Compounds measured in 30 50 -mL aliquots of seawater gently filtered through Whatman $\mathrm{GF} / \mathrm{F}$ filters $(\sim 0.7-\mu \mathrm{m}$ pore size) using a glass syringe were considered the "dissolved" fraction (DMSPd, DMSOd). The compounds retained on the GF/F filter were referred to as "particulate" (DMSPp, DMSOp). Those retained on polycarbonate filters of $5-\mu \mathrm{m}$ pore size (Millipore) were considered the "particulate $>5 \mu \mathrm{m}$ " fraction. Acetate filters were not used because they showed interferences with DMSO analysis. Concentrations presented in Fig. 2 are the means of the 2 consecutive sampling days.

Biological DMS and DMSPt consumptions and $D M S$ production - These were determined as described in Simó and Pedrós-Alió (1999b) and Simó et al. (2000). In brief, two 2.5-liter amber bottles with seawater from each
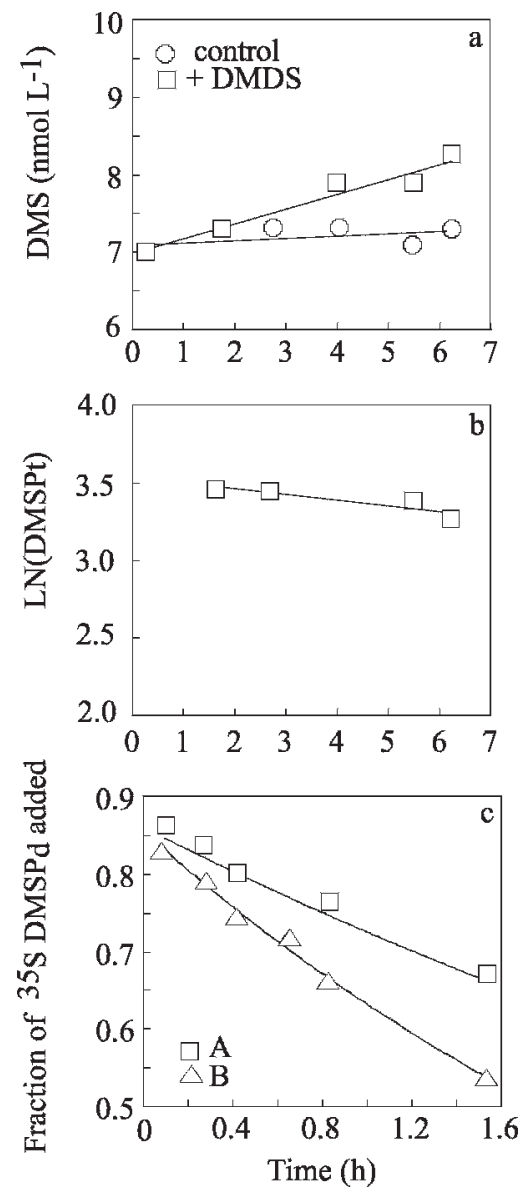

Fig. 1. Graphic results of the analytical methods employed to measure DMS production rates and DMS and DMSP consumption rates. These examples are taken from 04 August 2003. (a) Comparison between control (non-amended) and DMDS-amended bottles. The control bottle gives the net DMS production rate. The increase rate of DMS concentration in the DMDS-amended bottle gives the gross DMS production rate. Microbial DMS consumption is calculated by subtraction of the two slopes. (b) DMSPt consumption by the total community using the loss net curve method. (c) Bacterial DMSPd consumption measured as the rate of disappearance of added ${ }^{35} \mathrm{~S}-\mathrm{DMSPd}$ (duplicate bottles A and B are shown).

first sampling day were incubated in the dark at in situ temperature for $8 \mathrm{~h}$. Dimethyldisulfide (DMDS) was added to one of the bottles ( $260 \mathrm{nmol} \mathrm{L}^{-1}$ final conc.), to inhibit DMS consumption (Wolfe and Kiene 1993). Gross DMS production (nmol DMS L $\mathrm{L}^{-1} \mathrm{~d}^{-1}$ ) was measured as the rate of DMS accumulation in the +DMDS bottle. Microbial DMS consumption rate (nmol DMS $\mathrm{L}^{-1} \mathrm{~d}^{-1}$ ) was calculated from the difference between the slope of the DMS time course in the +DMDS bottles and the slope in the control (where both production and consumption occur, Fig. 1a).

DMSPt consumption by the whole community was measured using the method of the "net loss curve" in the dark (Simó et al. 2000). The rate constant of DMSPt consumption $\left(\mathrm{d}^{-1}\right)$ was obtained from the slope of the logarithmic disappearance of total DMSP concentrations 
in the control bottle (Fig. 1b). The DMSP consumption rate (nmol DMSPt L $\mathrm{L}^{-1} \mathrm{~d}^{-1}$ ) was calculated by multiplying this rate constant by the initial DMSPt concentration.

DMS yield-The DMS yield is defined as the ratio between the rates of DMS production and DMSP consumption (Simó 2001). The percent yield was calculated as (DMS production/ DMSP consumption) $\times 100$.

Microbial DMSPd consumption-We incubated 30-mL seawater samples from the first sampling day in the dark at in situ temperature with tracer levels of ${ }^{35} \mathrm{~S}$-DMSP $\left(1,000 \mathrm{dpm} \mathrm{mL} \mathrm{m}^{-1}\right.$ of a $214,230 \mathrm{~Bq} \mathrm{pmol}^{-1}$ stock). Fourmilliliter subsamples were taken over a short-term time course $(<2 \mathrm{~h})$, acidified to remove any endogenously formed ${ }^{35} \mathrm{~S}$-DMS, and stored at $4^{\circ} \mathrm{C}$ for $24 \mathrm{~h}$ in the dark. Untransformed ${ }^{35} \mathrm{~S}-\mathrm{DMSP}$ was converted into volatile ${ }^{35} \mathrm{~S}$ DMS by injection of $\mathrm{NaOH}$ into sealed vials, and trapped in $3 \% \mathrm{H}_{2} \mathrm{O}_{2}$-soaked wicks suspended in cups (Kiene and Linn 2000). DMSP loss rate constants were calculated from the exponential loss of ${ }^{35}$ S-DMSP with time (Fig. 1c). Microbial (bacterial plus phytoplankton) DMSP consumption rate was calculated as the product of the DMSPd concentration and the loss rate constant.

DMS ventilation - Semi-hourly wind speeds were obtained from the meteorological station of Malgrat. Instantaneous DMS air-sea exchange transfer velocities $\left(\mathrm{cm} \mathrm{h}^{-1}\right)$ were calculated from wind speed and sea-surface temperature using the parameterization of Nightingale et a1. (2000). The DMS air-sea exchange fluxes $\left(\mu \mathrm{mol} \mathrm{m}-2 \mathrm{~d}^{-1}\right)$ were calculated as the product of the DMS transfer velocity and DMS surface concentration. The mixing-layer averaged ventilation rate (nmol DMS $\mathrm{L}^{-1} \mathrm{~d}^{-1}$ ) was obtained by dividing the DMS exchange flux by the depth of the mixing layer. Semi-hourly DMS ventilation rates were averaged over the $24-\mathrm{h}$ period between the 2 consecutive days of sampling.

Estimation of photolysis rates-Photolysis rates were calculated by budgeting the difference of surface DMS concentrations between the 2 consecutive days and measured DMS production and DMS losses (Simó and Pedrós-Alió 1999b). The assumption behind this budget was that we were sampling the same water mass during this 24-h period. This was checked by comparing field data such as temperature, Chl $a$, inorganic nutrients concentrations, MLD, and DMS. In most of the cases, the assumption was supported. Because photolysis rates were obtained by algebraically budgeting various measurements and attributing the missing loss rate needed to close the budget to the photolysis sink, it is obvious that this attribution carries a large uncertainty. Standard errors of the order of $60 \%$ were calculated by error propagation.

Calculation of loss rate constants-The rate constants $\left(\mathrm{d}^{-1}\right)$ of DMS loss processes (microbial, ventilation, photolysis) were obtained by dividing the measured loss rates (nmol DMS $\mathrm{L}^{-1} \mathrm{~d}^{-1}$ ) by the DMS concentration (nmol DMS L-1) averaged for the 2 consecutive days.
Colored dissolved organic matter-Subsamples $(50 \mathrm{~mL})$ were filtered through $0.2-\mu \mathrm{m}$-pore-size, 47 -mm-diameter polysulfone filters (Supor-200; Gelman Sciences) using an $\mathrm{HCl}$-rinsed polycarbonate filtration device (Millipore). Subsamples $(20 \mathrm{~mL})$ were stored at $-20^{\circ} \mathrm{C}$ in ultraclean polypropylene vials until analysis. $\mathrm{cDOM}$ absorption values at $320 \mathrm{~nm}$ were measured using a UVIKON 923 $\mathrm{UV} / \mathrm{Vis}$ spectrophotometer with $10-\mathrm{cm}$ quartz cells. MilliQ water was used as a reference.

\section{Results}

Temperature, solar radiation, Chl a, and phytoplankton assemblages - Blanes Bay was characterized by a marked seasonality in water temperature: $12.8 \pm 1.6^{\circ} \mathrm{C}$ in winter and $24.6 \pm 1.1^{\circ} \mathrm{C}$ in summer (Fig. 2). Based on the stratification of the water column, the summer period was considered from May to August, whereas the winter period was from December to February. The solar radiation followed the same pattern as temperature. The mixing layer daily mean solar radiation averaged $23.1 \mathrm{~W} \mathrm{~m}^{-2}$ in winter and increased by a factor of $10\left(232.7 \mathrm{~W} \mathrm{~m}^{-2}\right)$ in summer (Fig. 2). The wind speeds on the sampling days did not vary significantly through the year $\left(1.5 \pm 0.3 \mathrm{~m} \mathrm{~s}^{-1}\right)$, and the salinity exhibited small variations in the range 36.0-38.7.

The winter period was characterized by higher nutrient concentrations and moderate $\mathrm{Chl} a$ concentrations (averaging $1.7 \mu \mathrm{g} \mathrm{Chl} a \mathrm{~L}^{-1}$ ). The typical winter bloom, mainly dominated by diatoms, was registered in the early March 2003 sampling. In December 2003, another winter bloom occurred, co-dominated by diatoms and haptophytes according to the distribution of taxon-specific pigments (Gutiérrez et al. unpubl. data). The summer periods exhibited low concentrations of inorganic nutrients and Chl $a$ (around $0.4 \mu \mathrm{g} \mathrm{Chl} a \mathrm{~L}^{-1}$ ) (Fig. 2). High abundances of Synechococcus were observed in the spring and summer months. These cyanobacteria co-occurred with nanoplanktonic haptophytes and microplanktonic dinoflagellates, which both reached their highest abundances in summer. Prochlorococcus abounded in autumn (Gutiérrez et al. unpubl. data).

Temporal variation in DMS, DMSP, and DMSO concentrations - Surface DMS concentrations showed a strong seasonality, with lowest values in winter (0.9 \pm $0.2 \mathrm{nmol} \mathrm{DMS} \mathrm{L}^{-1}$ ) and highest values in summer (11.3 \pm $5.2 \mathrm{nmol} \mathrm{DMS} \mathrm{L}^{-1}$ ), hence a maximum summer-to-winter ratio of ca. 12 (Fig. 2). DMS concentrations were well correlated with the ML-averaged solar radiation (Vallina and Simó 2007), and they did not correlate significantly withDMSPt or DMSOt concentrations. The ratio DMS : Chl $a$ followed the same seasonal pattern as DMS concentrations (Fig. 3).

Figure 2c shows the distribution of DMSPt into three pools (Particulate DMSP $<5 \mu \mathrm{m}$ [DMSPp $<5$ ], particulate DMSP $>5 \mu \mathrm{m}$ [DMSPp $>5$ ], and DMSPd) and how they varied with time. The seasonal pattern of DMSPt was mostly contributed to by DMSPp concentrations. The largest percentage of DMSPt was in the form of $\mathrm{DMSPp}<5$. On an annual average, DMSPp $>5$ only 


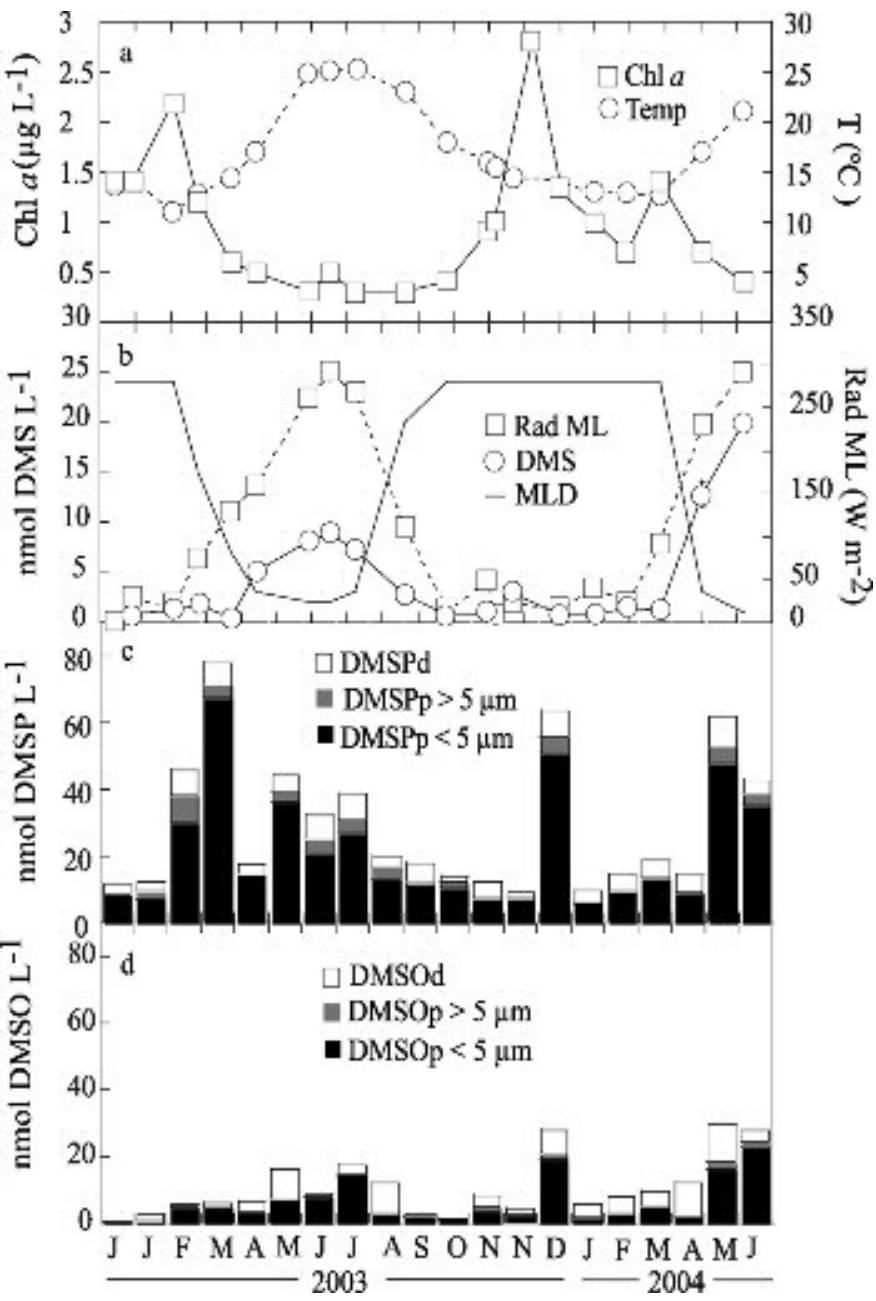

Fig. 2. Seasonal variation of (a) Chl $a$, sea-surface temperature, mixing layer depth (MLD), and radiation integrated in the mixing layer ( $\left.\mathrm{RAD}_{\mathrm{ML}}\right)$; (b) concentrations of dimethylated sulfur compounds; and concentrations of (c) DMSP and (d) DMSO divided into three pools: particulate $<5 \mu \mathrm{m}$, particulate $>5 \mu \mathrm{m}$, and dissolved.

accounted for $10 \% \pm 8 \%$ of DMSPp, indicating that the majority of DMSPp producers were in the size fraction smaller than $5 \mu \mathrm{m}$. DMSPp concentrations peaked (71.7 $\left.\mathrm{nmol} \mathrm{L}{ }^{-1}\right)$ in March, 1 month after the peak of Chl $a$, and in December $2003\left(55.8 \mathrm{nmol} \mathrm{L}^{-1}\right)$, concomitant with a second annual peak of Chl $a$. Values decreased during summer, reaching their annual lowest values in autumn. DMSPd never reached values higher than $8.8 \mathrm{nmol}$ DMSP L $^{-1}$ (annual average $5 \pm 2 \mathrm{nmol}$ DMSPd $\mathrm{L}^{-1}$ ). The DMSPp: Chl $a$ ratio showed a pattern similar to that of DMS concentrations, reaching the maximum values in summer months (Fig. 3).

Except for March 2003, DMSOt followed the pattern of DMSPt, but at lower concentrations. The seasonal variation of the three pools of DMSOt is shown in Fig. 2d. Like DMSPp, most of the DMSOp $(86 \% \pm 21 \%)$ occurred in the $<5-\mu \mathrm{m}$ fraction $(\mathrm{DMSOp}<5)$. In general, DMSOp concentrations increased from winter to summer. Maximum annual values were recorded in July 2003 (14.6 nmol

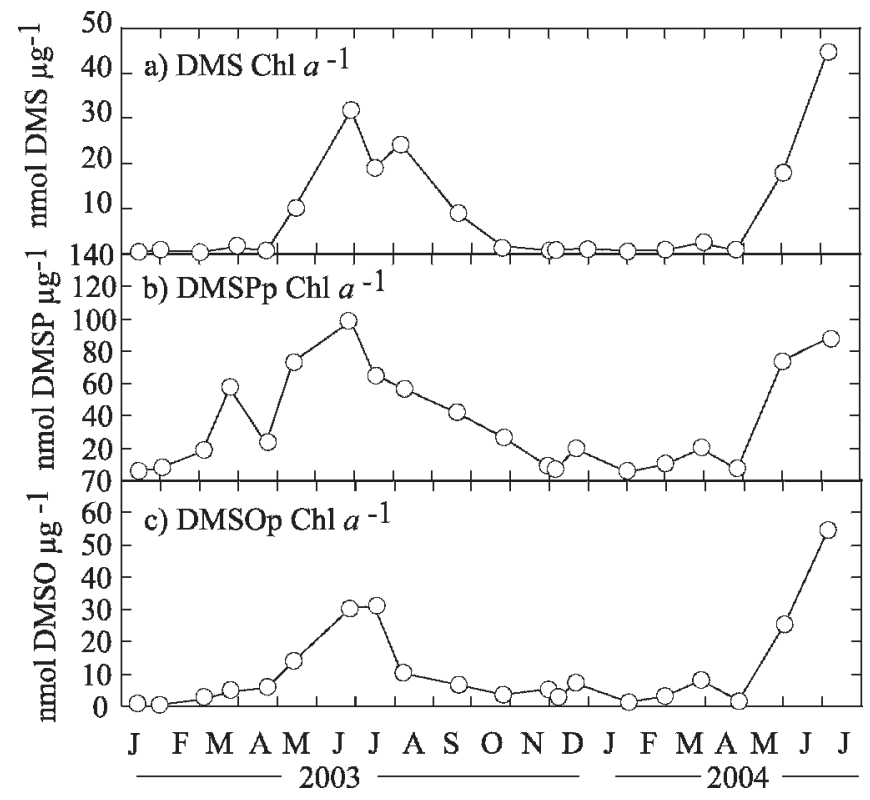

Fig. 3. Seasonality of Chl $a$-normalized concentrations of dimethylated sulfur compounds: (a) DMS, (b) particulate DMSP, and (c) particulate DMSO.

DMSOp L ${ }^{-1}$ ) and June 2004 (24.2 nmol DMSOp L ${ }^{-1}$ ). Exceptionally, in December 2003, DMSOp reached $21 \mathrm{nmol} \mathrm{L^{-1 }}$ in a peak concomitant with a peak of DMSPp. Annual DMSOd concentrations averaged $4 \pm$ $4 \mathrm{nmol}$ DMSOd L $\mathrm{L}^{-1}$ and did not show a clear seasonal pattern. The ratio DMSOp: Chl $a$ showed the same pattern as DMS concentrations (Pearson's, $r=0.95, n=20, p<$ 0.01 ), with higher values in summer and lower in winter (Fig. 3c).

DMSP consumption by the plankton community and contribution of the DMSPd consumers-The rates of DMSPt consumption by the total community ranged between 3.4 and $97.4 \mathrm{nmol}$ DMSPt L L ${ }^{-1} \mathrm{~d}^{-1}$ (Fig. 4). The highest values were found in late winter, coinciding with the peak of DMSPt (March 2003), and in June 2003. The rate constant of DMSPt consumption did not change significantly over the year; it averaged $0.79 \pm 0.16 \mathrm{~d}^{-1}$. This represents that, on annual average, $79 \%$ of the stock of DMSPt was renewed daily (Table 1).

Microbial consumption of DMSPd (measured with ${ }^{35} \mathrm{~S}$ DMSPd) showed a variation pattern similar to that of total DMSP consumption but without the outstanding peaks in March and June (Fig. 4). It averaged $11.1 \pm 7.2 \mathrm{nmol}$ DMSPd L $\mathrm{L}^{-1} \mathrm{~d}^{-1}$. DMSPd consumers (heterotrophic bacteria and phytoplankton) accounted for $52.2 \% \pm 25.2 \%$ of total DMSP consumption (annual average). Higher contributions were observed in summer and early winter (Fig. 4).

Gross DMS production - The DMSP-to-DMS conversion yield (DMS yield) represents the percentage of transformed DMSP that ends up as DMS. The annual variation of DMS yield (Fig. 5) showed roughly a seasonal pattern similar to that of DMS concentration, with 


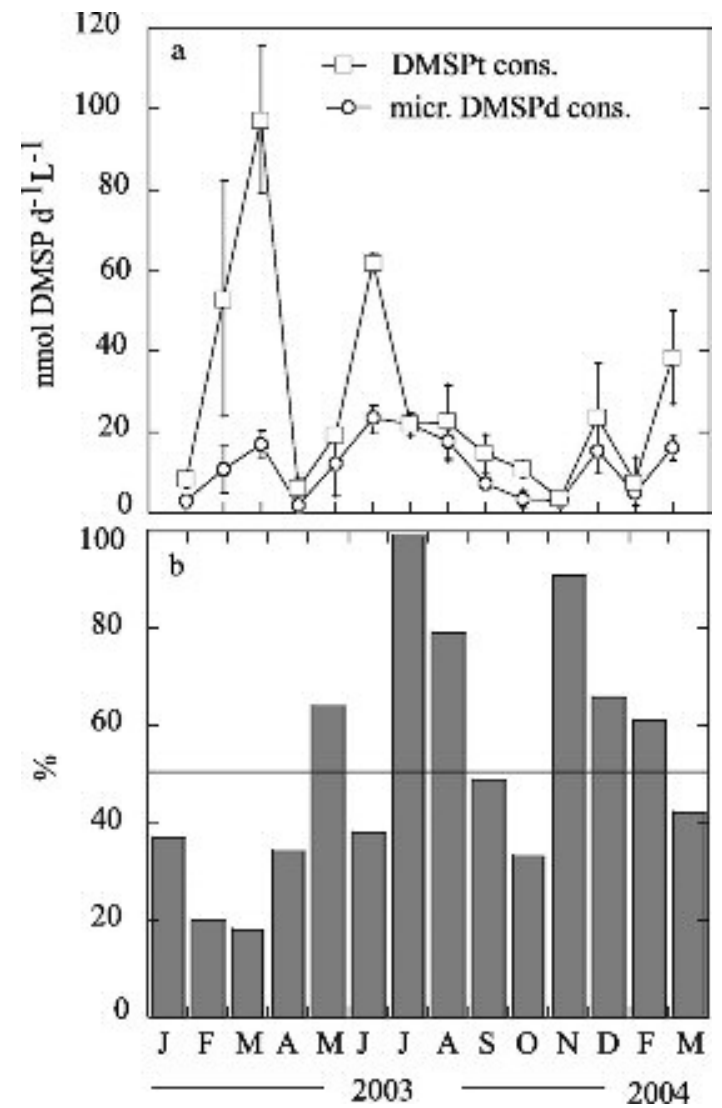

Fig. 4. (a) Monthly comparison of the rates of DMSP consumption by the total community (DMSPt cons) and microbial DMSPd consumption (micr. DMSPd cons). Error bars represent the uncertainty of the rates as given by the error of the slopes in incubations. (b) The contribution of bacteria and nonDMSP-producing phytoplankton to the total DMSP consumption. The line indicates the annual average (52\%).

maximum values during the summer period $(20 \% \pm 4.5 \%)$. Two data points fell off this general pattern: January and May 2003, with higher yields but never above $37 \%$.

Figure 6 shows the annual variation of gross DMS production that, on average, was higher in summer months $\left(6.0 \pm 1.7 \mathrm{nmol} \mathrm{DMS} \mathrm{L}^{-1} \mathrm{~d}^{-1}\right)$ than in the winter period (1.5 $\pm 0.7 \mathrm{nmol}$ DMS $\left.\mathrm{L}^{-1} \mathrm{~d}^{-1}\right)$. DMS production was significantly correlated with the ML-averaged solar radiation (Pearson's, $r=0.74, n=20, p<0.0001$ ) and with the ratio DMSOp: Chl $a$ (Pearson's, $r=0.74, n=20, p<$ $0.00001)$, and it showed the highest correlation with the DMSPp: Chl $a$ ratio (Pearson's, $r=0.93, n=20, p<$ 0.00001) (Table 2).

DMS loss processes: Microbial consumption, ventilation, and photolysis-Microbial DMS consumption did not show a clear seasonal pattern during the year (Fig. 6). In general, DMS turnover rates were in the same range of magnitude as DMS production $\left(1.7 \pm 0.4 \mathrm{nmol} \mathrm{DMS} \mathrm{L}^{-1} \mathrm{~d}^{-1}\right)$ with the exception of the summer months of 2003, when microbial DMS consumption $(2.1 \pm 0.7 \mathrm{nmol}$ DMS $\mathrm{L}^{-1} \mathrm{~d}^{-1}$ ) did not increase to reach the high levels of DMS production $\left(6.0 \pm 1.7 \mathrm{nmol} \mathrm{DMS} \mathrm{L}^{-1} \mathrm{~d}^{-1}\right)$. Microbial consumption rate constants averaged $0.7 \pm 0.2 \mathrm{~d}^{-1}$ through the year, with significantly lower values in summer months (Table 1).

Ventilation never dominated among DMS sinks (Fig. 7). Highest ventilation rates were observed in summer $(0.4 \pm$ $0.1 \mathrm{nmol} \mathrm{DMS} \mathrm{L}{ }^{-1} \mathrm{~d}^{-1}$, with $3 \mathrm{nmol} \mathrm{DMS} \mathrm{L}{ }^{-1} \mathrm{~d}^{-1}$ in June 2004), coinciding with shallower ML and higher DMS concentrations. Ventilation rate constants for the days of sampling averaged annually $0.02 \pm 0.01 \mathrm{~d}^{-1}$ (Table 1 ).

Calculated photolysis rates indicated that this process, or whatever makes up the missing loss rate, was the dominant DMS sink from February to July 2003, but not in April 2003, when we sampled after a storm event (Fig. 8). Calculated photolysis rates averaged annually $1.4 \pm$ $0.4 \mathrm{nmol}$ DMS $\mathrm{L}^{-1} \mathrm{~d}^{-1}$, whereas rate constants averaged $0.4 \pm 0.2 \mathrm{~d}^{-1}$. During the whole sampling series, photolysis rates showed a significant correlation with the MLaveraged solar radiation (Pearson's $r=0.54, n=19, p<$ 0.015 ) but rate constants did not (Table 2). It is important to notice this distinction because rate constants are independent of DMS concentrations.

Figure 8 shows the seasonal variation of the rate constants of DMS losses, along with the absorbance of cDOM and the nitrate $\left(\mathrm{NO}_{3}^{-}\right)$concentrations. The absorbance of cDOM did not exhibit a strong seasonality, but decreasing trends from Chl $a$ peaks toward the late summer were visible probably because of the photobleaching effect (Toole et al. 2003). A strong increase in cDOM absorbance occurred during the stormy period between September and October 2003. Summer waters were characterized by very low $\mathrm{NO}_{3}^{-}$concentrations $\left(<0.09 \mu \mathrm{mol} \mathrm{L}^{-1}\right)$, which were higher, yet variable, during the rest of the year $\left(0.21-7.11 \mu \mathrm{mol} \mathrm{L}^{-1}\right)$. Both cDOM and $\mathrm{NO}_{3}^{-}$have been suggested as photosensitizers for photochemical DMS destruction (Toole et al. 2003; Toole et al. 2004; Bouillon and Miller 2005). In our annual series, however, none of them showed a significant correlation with the calculated photolysis rate constants except for the periods March-September 2003 and March-July 2004 (that is, when solar radiation was higher, see Fig. 2), when the photolysis rate constant was seen to co-vary with cDOM absorbance (Fig. 8). No correlation was found between the potential photosensitizers and dissolved DMSO, one of the major products of DMS photooxidation (Kieber et al. 1996).

\section{Discussion}

The concentrations of dimethylated sulfur compounds in surface seawater result from a tight web of biological and physicochemical processes that are expected to undergo seasonal variations. We found that not only the DMS concentration, but also other variables like the DMSP : Chl $a$ and DMSO : Chl $a$ ratios showed clear seasonal patterns, with maximum values in summer and lower values in winter. This same seasonal pattern was followed by gross DMS production, which in turn was also well correlated with some physical factors such as the MLD and the MLaveraged solar radiation, suggesting that these physical forces might be driving the physiological responses of the 
Table 1. Monthly variation in rate constants $\left(\mathrm{d}^{-1}\right)$ of biological processes (total DMSPt consumption, microbial DMSPd consumption, and microbial DMS consumption) and abiotic processes (DMS ventilation and calculated DMS photolysis). Seasonal averages are given at the end of the table. W, Winter; SP, Spring; SU, Summer; AU, Autumn; -, no data.

\begin{tabular}{|c|c|c|c|c|c|c|c|c|}
\hline Month & Date & & MLD (m) & $\begin{array}{l}\text { Total DMSPt } \\
\text { consump. }\left(\mathrm{d}^{-1}\right)\end{array}$ & $\begin{array}{l}\text { Microbial DMSPd } \\
\text { consump. }\left(\mathrm{d}^{-1}\right)\end{array}$ & $\begin{array}{l}\text { Microbial DMS } \\
\text { consump. }\left(\mathrm{d}^{-1}\right)\end{array}$ & $\begin{array}{c}\text { DMS } \\
\text { ventilation }\left(\mathrm{d}^{-1}\right)\end{array}$ & $\begin{array}{c}\text { DMS } \\
\text { photolysis } \\
\left(\mathrm{d}^{-1}\right)\end{array}$ \\
\hline$\overline{\mathrm{Jan}}$ & 28 Jan 03 & W & 24 & 0.8 & 1.2 & 2.3 & 0.0 & 0.0 \\
\hline Feb & 04 Mar 03 & $\mathrm{~W}$ & 24 & 1.2 & 1.5 & 0.0 & 0.0 & 2.4 \\
\hline Mar & 25 Mar 03 & SP & 24 & 1.3 & 2.8 & 1.0 & 0.0 & 1.4 \\
\hline Apr & 22 Apr 03 & SP & 15 & 0.3 & 0.8 & 0.9 & 0.0 & 0.0 \\
\hline May & 13 May 03 & SU & 7 & 0.4 & 2.2 & 0.4 & 0.0 & 0.9 \\
\hline Jun & 25 Jun 03 & SU & 3 & 2.1 & 3.3 & 0.3 & 0.1 & 0.5 \\
\hline Jul & $14 \mathrm{Jul} 03$ & SU & 2 & 0.8 & 2.8 & 0.1 & 0.1 & 0.4 \\
\hline Aug & 04 Aug 03 & SU & 2 & 0.9 & 6.3 & 0.3 & 0.0 & 0.2 \\
\hline Sep & 16 Sep 03 & $\mathrm{AU}$ & 3 & 1.0 & 1.4 & 0.4 & 0.0 & 0.4 \\
\hline Oct & 21 Oct 03 & $\mathrm{AU}$ & 20 & 0.8 & 1.9 & 1.5 & 0.0 & 0.0 \\
\hline Nov & 25 Nov 03 & $\mathrm{AU}$ & 24 & 0.9 & - & 1.0 & 0.0 & 0.0 \\
\hline Nov & 02 Dec 03 & $\mathrm{AU}$ & 24 & 0.3 & 1.6 & 1.2 & 0.0 & 0.0 \\
\hline Dec & 16 Dec 03 & $\mathrm{~W}$ & 24 & 0.4 & 2.0 & 0.0 & 0.0 & 0.7 \\
\hline Jan & 26 Jan 04 & W & 24 & - & 2.7 & 1.2 & 0.0 & 0.9 \\
\hline Feb & $23 \mathrm{Feb} 04$ & $\mathrm{~W}$ & 24 & 0.6 & 1.0 & 1.5 & 0.0 & 0.4 \\
\hline Mar & 22 Mar 04 & SP & 24 & 1.4 & 3.1 & 0.7 & 0.0 & 0.0 \\
\hline Apr & 19 Apr 04 & SP & 24 & 0.2 & - & 0.5 & 0.0 & 0.1 \\
\hline May & 25 May 04 & SU & 3 & 0.0 & - & 0.5 & 0.1 & 0.1 \\
\hline \multirow[t]{9}{*}{ Jun } & 28 Jun 04 & SU & 1 & 1.9 & - & 0.4 & 0.2 & 0.1 \\
\hline & Mean & $\mathrm{W}$ & 24 & 0.8 & 1.7 & 1.0 & 0.0 & 0.9 \\
\hline & & SP & 22 & 0.8 & 2.2 & 0.7 & 0.0 & 0.4 \\
\hline & & $\mathrm{SU}$ & 3 & 1.0 & 3.6 & 0.3 & 0.1 & 0.4 \\
\hline & & $\mathrm{AU}$ & 18 & 0.7 & 1.6 & 1.0 & 0.0 & 0.1 \\
\hline & Std error & $\mathrm{W}$ & 0.0 & 0.1 & 0.3 & 0.4 & 0.0 & 0.4 \\
\hline & & SP & 2. & 0.3 & 0.6 & 0.1 & 0.0 & 0.3 \\
\hline & & SU & 0.9 & 0.3 & 0.7 & 0.0 & 0.0 & 0.1 \\
\hline & & $\mathrm{AU}$ & 5.0 & 0.2 & 0.1 & 0.2 & 0.0 & 0.1 \\
\hline
\end{tabular}

organisms. Assessing the importance of the coupling between biological processes and physical factors and the sign of action of the potential forces is crucial to understanding the dynamics of dimethylated sulfur compounds in the ocean and their role in the global sulfur cycle.

$D M S, D M S P$, and DMSO pools-DMS concentrations (0.5-8 nmol DMS L ${ }^{-1}$ ) were in the same broad range of those found in the west Mediterranean (0.3-7.3 nmol DMS $\mathrm{L}^{-1}$, Simó et al. 1997) and in other oligotrophic oceanic

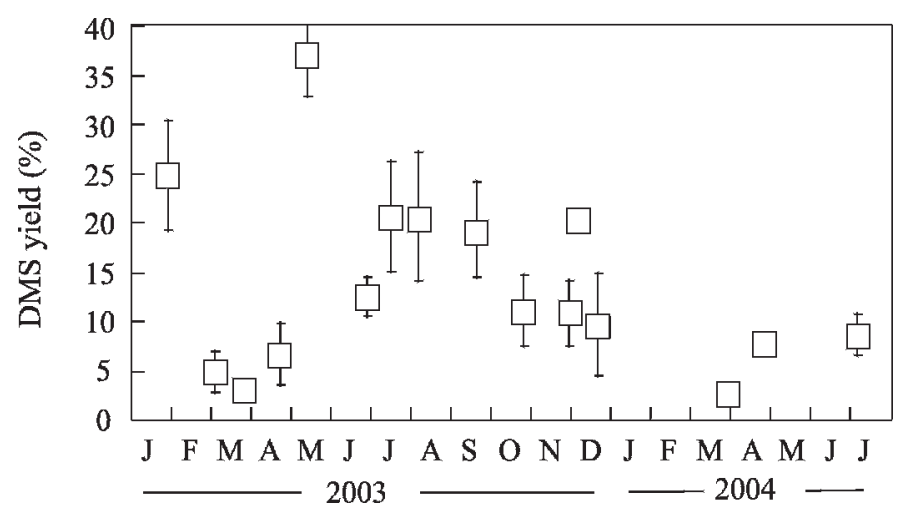

Fig. 5. Seasonal variation of the DMS yield (= DMS production $\times 100 /$ total DMSP consumption). waters (0.5-4 nmol DMS L ${ }^{-1}$, Dacey et al. 1998; 0.7$3.5 \mathrm{nmol}$ DMS L ${ }^{-1}$, Kettle et al. 1999). The pronounced seasonality of DMS concentrations observed in Blanes Bay is a common feature in the temperate and subtropical open ocean as well as in coastal regions where similar time series measurements have been performed (Leck et al. 1990; Turner et al. 1996; Dacey et al. 1998). In agreement with these studies, DMS concentrations peaked in mid-summer,

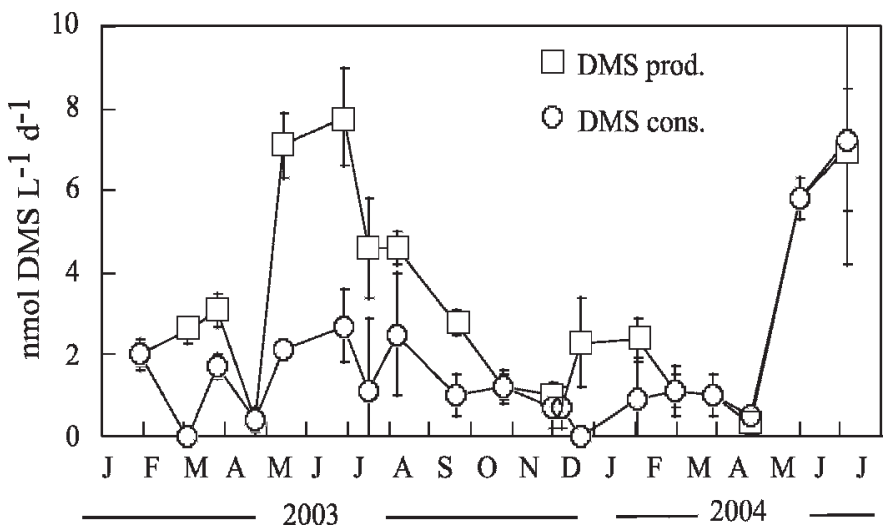

Fig. 6. Seasonal variation of DMS production and microbial DMS consumption rates. Error bars represent the uncertainty of the rates as given by the error of the slopes in incubations. 


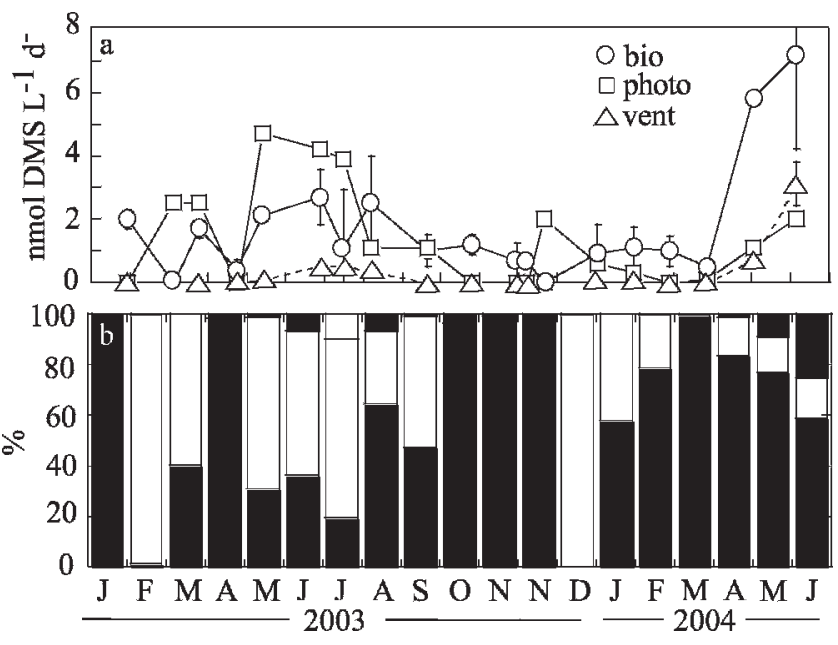

Fig. 7. (a) Seasonal variation of DMS loss rates: microbial consumption (bio), photolysis (photo), and ventilation (vent). (b) The vertical bars show the relative contribution of each DMS sink $($ bio $=$ lower filled, photo $=$ open, vent $=$ upper filled $)$. It should be noted that in April 2003 we sampled after a stormy event. Error bars represent the uncertainty of the rates as given by the error of the slopes in incubations.

i.e., $2-3$ months later than the DMS precursor DMSP, and in the season when phytoplankton biomass is at its minimum. This has been called the "DMS summer paradox" (Simó and Pedrós-Alió 1999a).

Most of the DMSP occurred in particulate form in the size fraction smaller than $5 \mu \mathrm{m}$. This size distribution did not change significantly through the year, suggesting that most DMSP producers were among the nanoplankton and below, despite the seasonal succession of the phytoplankton assemblages. Previous studies have reported similar results for other oceanic sites. Belviso et al. (2001) averaged values from highly contrasted trophic regions and found that DMSPp $<10 \mu \mathrm{m}$ accounted for $65 \% \pm 16 \%$ of total DMSPp. Scarratt et al. (2002) observed that most of total DMSP in the northwest Atlantic was in the $2-11-\mu \mathrm{m}$ size fraction.

Attempts to correlate DMS or DMSP to Chl $a$ concentrations have failed in many studies (Leck et al. 1990; Dacey et al. 1998; Kettle et al. 1999), because of the taxonspecificity of DMSP biosynthesis and a potential physiological regulation of the intracellular DMSP content. In our study, besides a lack of proportionality between dimethylated sulfur compounds and Chl $a$ we also observed a strong seasonality of the ratio DMS: Chl $a$, similar to that found in other oceanic regions (see a compilation in Uher et al. 2000). A remarkable finding of our work is that the DMSP : Chl $a$ and DMSO : Chl $a$ ratios also exhibited this same seasonal pattern (Fig. 3). Identifying whether this pattern resulted mainly from phytoplankton succession or physiological adaptations is not a straightforward task. The succession of phytoplankton in Blanes Bay has been studied (e.g., Mura et al. 1996). In brief, diatoms dominate in the winter period, followed by a succession toward assemblages with high abundances of Synechococcus (spring and late summer) and Prochlorococcus (autumn).

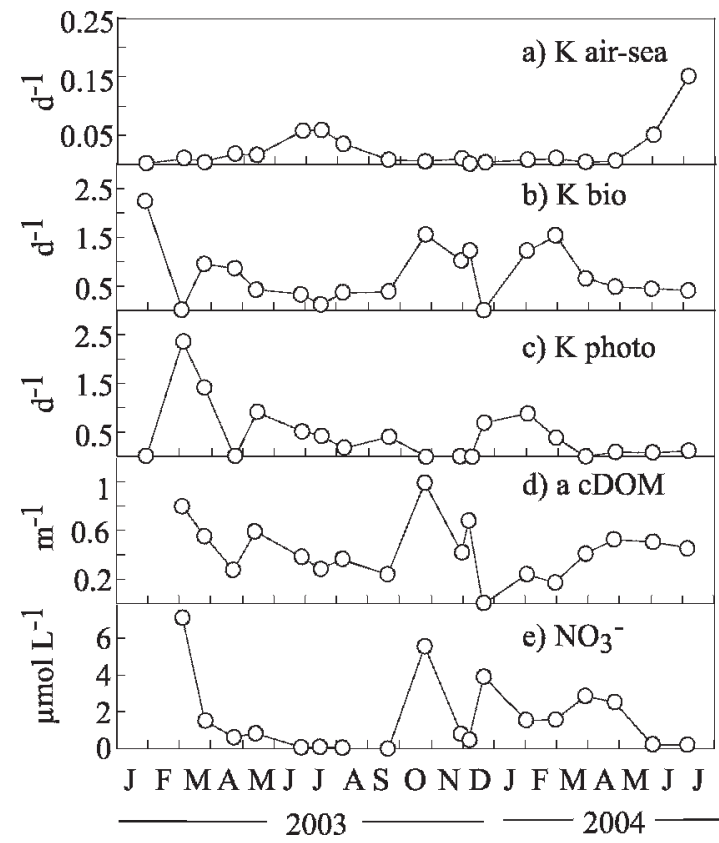

Fig. 8. (a) Seasonal variation of the rate constants of DMS ventilation ( $\mathrm{K}$ air-sea), (b) DMS microbial consumption ( $\mathrm{K}$ bio), and (c) DMS photolysis (K photo). (d) The absorbance of colored components of dissolved organic matter at $320 \mathrm{~nm}$ (a cDOM), and (e) nitrate concentrations $\left(\mathrm{NO}_{3}^{-}\right)$are also shown.

In our annual study, nanophytoplankton was dominated by haptophytes from March to October and, interestingly, in the $>3-\mu \mathrm{m}$ size fraction, a peak of dinoflagellate numbers was observed from June to August (Gutiérrez et al. unpubl.data). Thus, elevated abundances of two known groups of high DMSP producers (haptophytes and dinoflagellates, Keller et al. 1989) coincided in the summer period.

The fact that DMSO : Chl $a$ followed the same pattern as DMSP : Chl $a$ supports the suggestion that physiological adaptation also plays a role. An algal origin for DMSO has already been reported in previous studies (Simó et al. 1998; Simó and Vila-Costa 2006). With a culture manipulation study, Sunda et al. (2002) postulated that phytoplankton increase intracellular DMS and DMSP relative to Chl $a$ levels under exposure to high UV radiation doses. These authors proposed a cascade of reactions that starts with DMSP and evolves DMS and DMSO, which all scavenge hazardous reactive oxygen species and protect the cell against oxidative stress. This cascade would cause DMS leakage from, and possibly DMSO accumulation in, the algal cell (Sunda et al. 2002; Simó and Vila-Costa 2006). It is very likely that this high-light adaptation contributed to the elevated DMS : Chl $a$, DMSP : Chl $a$, and DMSO :Chl $a$ ratios obtained in summer and to the seasonal correlation between these ratios and the ML-averaged solar radiation. These ratios could also be affected by reduced Chl $a$ in high light; biovolume measurements and conversion to carbon showed indeed that $\mathrm{C}: \mathrm{Chl} a$ ratios increased in summer by three-fold (Vila-Costa et al. unpubl. data). Such a decrease in Chl $a$ content was lower than the 5- to $>10$-fold increase 
Table 2. Pearson correlation coefficients ( $r$ ) for biological rate constants of DMSP consumption by total community (DMSPt cons), microbial DMSPd consumption (DMSPd cons), DMS losses (microbial consumption [K bio], photolysis [K photo], and ventilation [K vent]), and gross DMS production versus physical or easily measurable parameters. Significant correlations at the $95 \%$ confidence level are in bold.

\begin{tabular}{|c|c|c|c|c|c|c|c|c|c|c|}
\hline & units & MLD & SST & $\operatorname{Rad}(M L)$ & $\mathrm{NO}_{3}^{-}$ & $\mathrm{cDOM}$ & $\mathrm{NH}_{4}^{+}$ & $\begin{array}{l}\text { DMSPp: } \\
\text { Chl } a\end{array}$ & $\begin{array}{l}\text { DMSOp: } \\
\text { Chl } a\end{array}$ & $\begin{array}{l}\text { DMS : } \\
\text { Chl } a\end{array}$ \\
\hline K DMSPt cons & $\mathrm{d}^{-1}$ & -0.07 & 0.23 & 0.21 & 0.14 & -0.03 & 0.32 & 0.47 & 0.40 & 0.48 \\
\hline K DMSPd cons & $\mathrm{d}^{-1}$ & -0.48 & 0.54 & 0.60 & -0.26 & -0.09 & -0.11 & 0.50 & 0.36 & 0.68 \\
\hline $\begin{array}{l}\text { DMS prod rate } \\
\text { DMS losses: }\end{array}$ & $\mathrm{nmol} \mathrm{L} \mathrm{L}^{-1} \mathrm{~d}^{-1}$ & -0.75 & 0.60 & 0.74 & -0.33 & -0.11 & 0.03 & 0.93 & 0.74 & 0.80 \\
\hline $\mathrm{K}$ bio & $\mathrm{d}^{-1}$ & 0.52 & -0.42 & -0.60 & 0.11 & 0.20 & 0.18 & -0.53 & -0.54 & -0.56 \\
\hline $\mathrm{K}$ vent & $d^{-1}$ & -0.80 & 0.76 & 0.91 & -0.43 & -0.37 & 0.06 & 0.74 & 0.93 & 0.88 \\
\hline $\mathrm{K}$ photo & $\mathrm{d}^{-1}$ & 0.07 & -0.35 & -0.12 & 0.49 & 0.31 & 0.38 & 0.11 & -0.09 & -0.13 \\
\hline
\end{tabular}

in DMS : Chl $a$, DMSP : Chl $a$, and DMSO : Chl $a$ ratios (Fig. 3).

DMSOd can result from DMS photolysis (Kieber et al. 1996), microbial DMS oxidation (Del Valle et al. 2006), and algal DMSO release (Simó et al. 1998). The relative importance of each of these sources has never been quantified in field studies. The absence of any significant correlation between DMSOd and either calculated DMS photolysis or measured DMS consumption rates could be explained by the fact that both biological DMS consumption and photooxidation give rise to various products. For example, Kieber et al. (1996) found that only $14 \%$ of DMS was photooxidized to DMSOd, and Del Valle et al. (2006) observed that microorganisms converted DMS into DMSOd or $\mathrm{SO}_{4}^{-}$, and the switch between both pathways was probably dependent on the composition of the microbial assemblage or the availability of organic carbon. In contrast, DMSOp was positively correlated to DMSPp (Pearson's $r=0.66, n=20, p<0.01$ ). The ratio DMSP:DMSO is inversely correlated with seawater temperature along a wide range of latitudes and also in this Blanes Bay time series (Simó and Vila-Costa 2006). These authors suggested that, in this context, temperature may be a proxy for upper mixing and sunlight exposure, so that the aforementioned inverse correlation would be indicative of a higher occurrence of DMSOp in highly irradiated waters, which would support an antioxidant role of DMSO in the algal cells.

DMSP loss processes: Contribution of microbial DMSPd consumers - DMSPt consumption rates measured with the dark net loss method were always higher than DMSPd consumption rates measured with ${ }^{35} \mathrm{~S}$-DMSP. The range of DMSPt consumption (3-60 nmol DMSP $\mathrm{L}^{-1} \mathrm{~d}^{-1}$ ) and DMSPd turnover (2-24 nmol DMSP L ${ }^{-1} \mathrm{~d}^{-1}$ ) were similar to previous studies in coastal and open-ocean waters (1.4 16.8, Ledyard and Dacey 1996; 7-76, Simó et al. 2000; 3.8 (open ocean) to 39 (coastal), Kiene et al. 2000; 17-20, Zubkov et al. 2002; 1.1-20.5, Malmstrom et al. 2005, where the units of all are nmol DMSP $\mathrm{L}^{-1} \mathrm{~d}^{-1}$ ), never reaching the high values measured in dense blooms of strong DMSP producers (Van Duyl et al. 1998; Simó et al. 2000).

Turnover times of DMSPt annually averaged $1.3 \mathrm{~d}$, implying that $79 \%$ of the stock was renewed daily by grazing, viral attack, and autolysis. Interestingly, according to the compilation by Calbet and Landry (2004), the average of daily phytoplankton growth consumed by microzooplankton in oligo- and mesotrophic waters is as high as $67 \%$. Being that the other phytoplankton losses are much more poorly constrained, it seemed plausible that microzooplankton contributed a major fraction of algal DMSP turnover.

It is generally accepted that release of DMSPd and its subsequent use by heterotrophic bacterioplankton is the dominant mechanism for DMSP transformation (Kiene et al. 2000; Zubkov et al. 2002). DMSPd indeed is a very labile compound and a good substrate for the growth of a broad spectrum of marine bacteria (Malmstrom et al. 2004; Vila-Costa et al. 2007). But algal DMSP is also transformed in the food web via a variety of other processes, including cleavage by the DMSP producers (Stefels 2000, Sunda et al. 2002) or loss upon zooplankton grazing on phytoplankton (Dacey and Wakeham 1986, Wolfe and Steinke 1996; Archer et al. 2003). The actual contribution of heterotrophic bacteria to communitymediated total DMSP loss remained unknown. By the simultaneous use of two different methods (dark DMSPt net loss and radiolabeled DMSPd loss), we have shown that, on average, $52 \%$ of total DMSP transformations occurred through the DMSPd pool. This sets an upper end for the contribution of heterotrophic bacterioplankton to DMSP loss, because we have recently reported that non- or low-DMSP-producing phytoplankton also act as a sink for DMSPd (Vila-Costa et al. 2006), and there is the possibility that phytoplankton possessing extracellular lyases also contribute to DMSPd cleavage. In any case, this contribution of DMSPd consumers to total DMSP loss changed during the year, and, interestingly, it was minimal coinciding with the maxima of DMSPp production (February, March, and June 2003, March 2004), leaving room for the dominance of DMSPp loss processes such as microzooplankton grazing. This finding suggests that the coupling between microzooplankton-grazing and DMSPproducing phytoplankton growth was tighter during high biomass or production periods, as described previously for total phytoplankton assemblages (Strom et al. 2001). However, this likely higher grazing pressure in the winter period was not reflected in an increase of DMS concentrations as it could be expected after other studies (Belviso et al. 1990; Levasseur et al. 1996; Archer et al. 2003). This 
might have been masked by the low frequency of our sampling schedule. Overall, the role of phytoplankton and zooplankton in DMSP consumption is more relevant than previously believed, and their effect as sources of DMS must be explored in more detail.

DMS production versus microbial DMS consumptionMeasurements of DMS production still represent a challenge. We chose to use the DMDS inhibition method (Wolfe and Kiene 1993; Simó and Pedrós-Alió 1999b). This method does not allow independent measurements of DMS consumption and production, and it might cause either underestimation of production and consumption rates if full inhibition were not achieved or overestimation by bottle effects during incubations (Kiene and Slezak 2006). Nonetheless, this method has proven useful in a number of studies where it has provided reasonable results (e.g., Van Duyl et al. 1998; Wolfe et al. 1999; Simó et al. 2000).

DMS production and consumption rates were within the same range $\left(0.1-7.7 \mathrm{nmol}\right.$ DMS $\left.\mathrm{L}^{-1} \mathrm{~d}^{-1}\right)$ than most measured in other marine regions (generally $0.3-10 \mathrm{nmol}$ DMS L $\mathrm{L}^{-1} \mathrm{~d}^{-1}$, see a compilation in Simó 2004), and much lower than those measured in blooms of DMSP producers (Van Duyl et al. 1998; Simó et al. 2000).

In general, DMS consumption was of a magnitude similar to DMS production. The most notable exception was the late spring and summer months of 2003, particularly May and June, when the increase of DMS production was not matched by DMS consumption (Fig. 6). Reasons for this decoupling might be either kinetic or environmental. Kinetic studies have consistently found that bacterial DMS consumption saturates at 10-30 nmol DMS L ${ }^{-1}$ when concentrations rise rapidly, so that higher DMS concentrations caused by high production rates would lead to a decoupling between DMS consumption and production (Kiene 1992; Wolfe et al. 1999; Scarratt et al. 2000). Nevertheless, in studies conducted with blooms of DMSP producers high DMS consumption rates have been measured concomitantly with high DMS production rates (e.g., Simó et al. 2000). Also, in our study, the highest DMS concentrations (close to $20 \mathrm{nmol} \mathrm{L}^{-1}$ ) in May-June 2004 were associated with highly coupled production and consumption rates. Thus, saturation of DMS consumption seems not to be a universal phenomenon. Inhibition of DMS consumption by environmental factors in the summer period arises as an alternative (nonexclusive) explanation. It is likely that UV radiation, enhanced by the shallow stratification of the water column, caused inhibition of DMS-consuming bacteria (Slezak et al. 2001; Simó 2004) in summer 2003, as observed recently in experiments conducted in the open ocean (Toole et al. 2006).

Interestingly, contrasting with the results of Slezak et al. (2001), who found that DMSPd loss was inhibited by UV, no inhibition of microbial DMSPd consumption was apparent in the summer period. Rather, high rates were recorded in this period (Fig. 4) and, over the annual cycle, rate constants of DMSPd consumption were positively correlated with the ML-averaged solar radiation dose (Table 2). In contrast, bacterial DMS consumption rate constants were negatively correlated with the ML-averaged solar radiation dose (Table 2). This different behavior through seasons may first result from a different phylogenetic identity of DMS- and DMSP-consuming bacteria: DMSP consumption is carried out by a wide spectrum of marine bacteria (Malmstrom et al. 2004; Vila-Costa et al. 2007), whereas DMS consumption seems to be restricted to some specific groups (Vila-Costa et al. 2006). It has been shown recently that some phylogenetic groups are more resistant to solar radiation than others (Alonso-Sáez et al. 2006). Additionally, other recent studies have shown the capacity of non-DMSP-producing photoautotrophs to assimilate DMSPd from the medium (Malmstrom et al. 2005; Vila-Costa et al. 2006). Because pigmented cells are expected to have higher resistance to photoinhibition, their contribution as a DMSPd sink might partially explain the higher DMSP consumption rates observed in summer. Finally, DMSP-producing algae with extracellular DMSP lyase activity might be a further sink for DMSPd (Stefels and van Boekel 1993; Niki et al. 2000). Unlike DMSPassimilating phytoplankton, exo-DMSP-cleaving algae would be a source of DMS and would contribute to the increased DMS yield in summer.

DMS loss processes - In agreement with previous studies, ventilation was a minor DMS sink (Simó and PedrósAlió 1999b; Toole et al. 2006), whereas estimated photolysis and microbial consumption alternated their dominance throughout the year (Fig. 7). Ventilation was significantly higher in the summer period, because of higher surface DMS concentrations. DMS air-sea flux ranged from $0.032 \mu \mathrm{mol}$ DMS m $\mathrm{m}^{-2} \mathrm{~d}^{-1}$ to $3.1 \mu \mathrm{mol}$ DMS m $\mathrm{m}^{-2} \mathrm{~d}^{-1}$, values slightly lower than those measured in oceanic sites (e.g., Uher et al. 2000).

Altogether, DMS losses averaged $0.4 \mathrm{~d}^{-1}( \pm 0.2)$, thus giving turnover times of $2.5 \mathrm{~d}$, slower than those measured in a bloom of coccolithophores (0.4-1.6 d, Simó and Pedrós-Alió 1999b) and within the range of those measured in the equatorial Pacific (1-4 d, Kieber et al. 1996) and in the North Atlantic drift (2.2-3.9 d, Wolfe et al. 1999).

In a short-term (15 d) study, Simó and Pedrós-Alió (1999b) observed that the relative importance of each DMS sink was strongly dependent on the variability of its physical driver. Over a seasonal scale in the Sargasso Sea, Toole et al. (2003) showed that photolysis was higher in the summer period mainly because of the higher doses of solar radiation. In Blanes Bay, calculated photolysis dominated from February to July 2003, and microbial consumption dominated during the second half of that year and the first half of 2004. DMS photolysis occurs through secondary photosensitizers (such as $\mathrm{cDOM}$ or $\mathrm{NO}_{3}^{-}$) that absorb the photon flux at wavelengths $>260 \mathrm{~nm}$, leading to the photodestruction of DMS (Toole et al. 2003, 2006). Although highly uncertain because of the estimation method, variations of the DMS photolysis rate constant correlated with $\mathrm{cDOM}$ absorbance during the period when the daily solar radiation in the mixing layer was higher (March to September, Fig. 8). During fall and winter, when microbial consumption was the dominant DMS sink, cDOM absorption somehow co-varied with this biological 


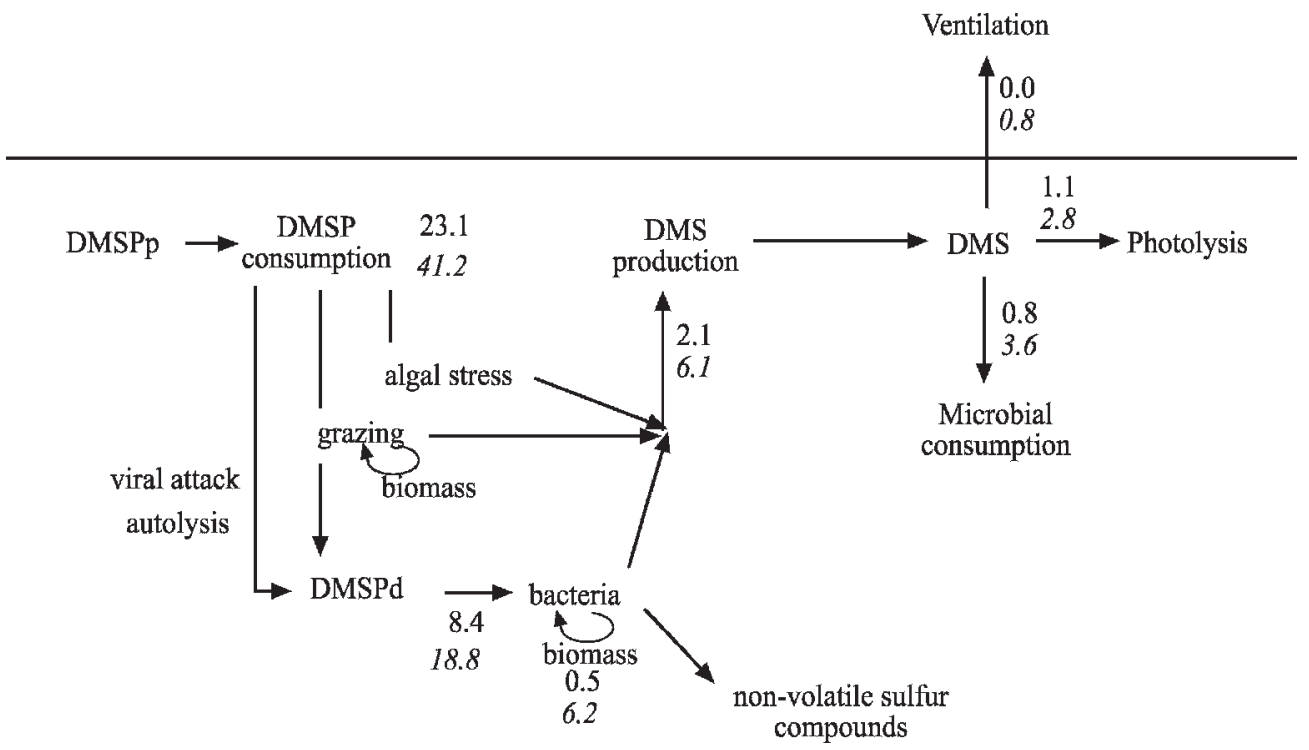

Fig. 9. Diagram of the DMS(P) cycle comparing contrasted measured DMSP and DMS transformation rates (nmol S L-1 $\mathrm{d}^{-1}$ ) in winter (December to February) and summer (May to August). Data on bacterial DMSP assimilation are taken from Vila-Costa et al. (2007). Winter data are shown above summer data (italics) (nmol S L-1 $\mathrm{d}^{-1}$ ).

loss. Although cDOM and dissolved organic carbon (DOC) concentrations can be independent of each other (Siegel et al. 2002), cDOM absorbance in fall and winter seems to reflect DOC bioavailability to bacteria. cDOM absorbances in Blanes Bay were similar to those measured in coastal stations (Toole et al. 2006) and slightly lower than values typical of the open ocean (Nelson and Siegel 2002). A period of stormy weather started late September 2003, possibly affecting the levels and composition of cDOM.

General picture of the seasonal cycle of dimethylated sulfur compounds in Blanes Bay-The methods we used to measure the fluxes of DMSP and DMS have a 1-d resolution time; they are not equal to monthly changes. Thus, we cannot see the monthly trends of the fluxes, but we can track variations month by month and compare contrasted periods as it is shown in Fig. 9, comparing winter versus summer.

In our year-round study, attempts to relate DMSP consumption to environmental factors only gave a significant correlation with the ML-averaged solar radiation dose (Table 2). Gross DMS production, microbial DMS loss, and DMS ventilation showed correlation with almost all physical factors: MLD, sea surface temperature (SST), and the ML-averaged solar radiation (Table 2). DMSP transformations seem to be mainly driven by the dynamics of the food web, whereas DMS concentrations seem to ultimately be determined by physical forces as it had been postulated in previous studies (Simó and PedrósAlió, 1999b; Toole and Siegel 2004).

DMSP consumption did not show the same year-round pattern as DMS concentration or production, which resulted in a seasonally changing yield of DMSP cleavage into DMS. Starting from 5\% in February 2003, it increased to $20 \%$ in mid-summer and decreased again as it went into autumn and winter. The annual average (12\%) is at the lower end of DMS yields measured in other oceanic and coastal sites (mostly 5-80\%, average 30\%, Simó and Pedrós-Alió 1999a). We have shown that the DMS accumulation in the summer period (the "summer paradox") resulted mainly from an increase of net biological DMS production. From our data, can we elucidate who were the main players in this biological decoupling?

As discussed before, the increase of DMS production in summer cannot be attributed to bacterioplankton only. Although DMSPd consumption (mostly bacterial but also phytoplankton-mediated) accounted for most of all DMSP transformations $(70 \% \pm 13 \%)$ in the summer period, the DMSPd-to-DMS yield measured in one experiment in August $(8.0 \% \pm 2.5 \%)$ did not fully explain the DMS yield by the total community $(20.6 \% \pm 4.0 \%)$. In fact, bacterial DMSP assimilation was higher in this period (see Fig. 9; data from Vila-Costa et al. 2007) and diverted a larger fraction of DMSP from giving rise to DMS production. Upon grazing by zooplankton, algal DMSP may follow three transformation pathways (Fig. 9): (1) release to the DMSPd pool, which becomes available to heterotrophic bacteria, non-DMSP-producing phytoplankton, and algal extracellular DMSP lyases, (2) assimilation by the grazer (Tang et al. 2001; Archer et al. 2003; Tang and Simó 2003), and (3) cleavage into DMS by algal DMSP lyases upon release, a process favored by cell disruption during capture, ingestion, or digestion (Dacey and Wakeham 1986; Wolfe and Steinke 1996), and by gut-associated bacteria (Tang et al. 2001). In a compilation work, grazing of microzooplankton was found to be relatively constant at the annual scale (Calbet and Landry 2004), although there also is evidence for higher grazing pressure during productive periods (Strom et al. 2001). Thus, there is no indication that microzooplankton impact on DMSP producers should be 
higher in summer. Besides, mesozooplankton never accounted for more than $6 \%$ of the grazing effect of the whole community in a seasonal study conducted $45 \mathrm{~km}$ south of our sampling site (Broglio et al. 2004). It seems thus plausible that a large proportion of the summer increase in DMS production comes from the DMSP producers themselves. The anti-oxidant hypothesis proposes that DMS leaks out of the algal cell as a byproduct of a radical scavenging reaction chain in response to exposure to high levels of UV radiation (Sunda et al. 2002). Because haptophytes and dinoflagellates abounded during highlight conditions, it might also be that extracellular DMSP lyases were more active in summer (Stefels and van Boekel 1993; Niki et al. 2000). In both cases, summer would then be the season when algal DMS production would be maximal. This conclusion is supported by the good correlation between DMS production rates, the DMSP:Chl $a$ and DMSO:Chl $a$ ratios, and the MLaveraged solar radiation doses.

Overall, our results provide insights into the complex mechanisms of the epipelagic ecosystem that configure the oceanic DMS cycle. The occurrence of the DMS summer paradox seems to support the hypothesized feed-back between climate and DMS production by marine biota at the seasonal scale. Climate forces typical of summer months, such as the increase of solar radiation and the associated increase of the air-to-sea heat flux, result in shallower stratification of the water column that in turn magnifies the doses of solar radiation in the mixing layer. These physical forces drive abiotic transformation processes, and also the photobiological responses of organisms that result in larger net biological DMS production, as it has been observed in this study. Our results from Blanes Bay point to algal DMSP-lyase activity as a more important DMS source than previously considered. More detailed quantitative information on the relative contributions of the main players (phytoplankton, grazers, and heterotrophic bacteria) to the production of DMS in other systems, as well as improved understanding of how DMS production processes are affected by solar radiation and other environmental factors, will greatly improve efforts to model the DMS cycle.

\section{References}

Alonso-Saez, L., J. M. Gasol, T. Lefort, J. Hofer, and R. Sommaruga. 2006. Effect of natural sunlight on bacterial activity and differential sensitivity of natural bacterioplankton groups in northwestern Mediterranean coastal waters. Appl. Environ. Microbiol. 72: 5806-5813.

Archer, S. D., C. E. Stelfox-Widdicombe, G. Malin, and P. H. BURKILL. 2003. Is dimethyl sulphide production related to microzooplankton herbivory in the southern North Sea? J. Plankton Res. 25: 235-242.

Bates, T., J. Cline, R. Gammon, and S. Kelly-Hansen. 1987. Regional and seasonal variations in the flux of oceanic dimethylsulfide to the atmosphere. J. Geophy. Res. 92: 2930-2938.

Belviso, S., H. Claustre, and J. C. Marty. 2001. Evaluation of the utility of chemo-taxonomic pigments as a surrogate for particulate DMSP. Limnol. Oceanogr. 46: 989-995.
S.-K. Kim, F. Rassoulzadegan, B. Krajka, B. C. Nguyen, N. Mihalopoulos, and P. Buat-Menard. 1990. Production of dimethylsulfonium propionate (DMSP) and dimethylsulfide (DMS) by a microbial food web. Limnol. Oceanogr. 35: 1810-1821.

Boulllon, R. C., AND W. L. Miller. 2005. Photodegradation of dimethyl sulfide (DMS) in natural waters: Laboratory assessment of the nitrate-photolysis-induced DMS oxidation. Environ. Sci. Technol. 39: 9471-9477.

Broglio, E., E. Saiz, A. Calbet, I. Trepat, and M. Alcaraz. 2004. Trophic impact and prey selection by crustacean zooplankton on the microbial communities of an oligotrophic coastal area (NW Mediterranean Sea). Aquat. Microb. Ecol. 35: $65-78$.

Burkill, P. H., S. D. Archer, C. Robinson, P. D. Nightingale, S. B. Groom, G. A. Tarran, and M. V. Zubkov. 2002. Dimethyl sulphide biogeochemistry within a coccolithophore bloom (DISCO): An overview. Deep-Sea Res. II 49: 2863-2885.

Calbet, A., and M. R. Landry. 2004. Phytoplankton growth, microzooplankton grazing, and carbon cycling in marine systems. Limnol. Oceanogr. 49: 51-57.

Charlson, R. J., J. E. Lovelock, M. O. Andreae, and S. G. WARREN. 1987. Oceanic phytoplankton, atmospheric sulfur, cloud albedo and climate. Nature 326: 655-661.

Dacey, J. W. H., F. A. Howse, A. F. Michaels, and S. G. WAKenAm. 1998. Temporal variability of dimethylsulfide and dimethylsulfoniopropionate in the Sargasso Sea. Deep-Sea Res. I 45: 2085-2104.

-, And S. G. Wakeham. 1986. Oceanic dimethylsulfide: production during zooplankton grazing on phytoplankton. Science 233: 1314-1316.

del Valle, D., D. J. Kieber, and R. P. Kiene. 2006. Depthdependent fate of biologically-consumed dimethylsulfide in the Sargasso Sea. Mar. Chem. 103: 197-208.

Keller, M. D., W. K. Bellows, and R. R. L. Guillard. 1989. Dimethyl sulfide production in marine phytoplankton, p. 167-182. In E. Saltzman and W. J. Cooper [eds.], Biogenic sulfur in the environment. Am. Chemical Soc.

Kettle, A. J., AND others. 1999. A global database of sea surface dimethylsulfide (DMS) measurements and a procedure to predict sea surface DMS as a function of latitude, longitude, and month. Global Biogeochem. Cycles 13: 399-444.

Kieber, D. J., J. JiAo, R. P. Kiene, AND T. S. Bates. 1996. Impact of dimethylsulfide photochemistry on methyl sulfur cycling in the Equatorial Pacific Ocean. J. Geophys. Res. 101: 3715-3722.

KIENE, R. P. 1992. Dynamics of dimethyl sulfide and dimethylsulfoniopropionate in oceanic seawater samples. Mar. Chem. 37: 29-52.

- AND L. J. LinN. 2000. The fate of dissolved dimethylsulfoniopropionate (DMSP) in seawater: Tracer studies using ${ }^{35}$ S-DMSP. Geochim. Cosmochim. Acta 64: 2797-2810. AND J. A. BRuton. 2000. New and important roles for DMSP in marine microbial communities. J. Sea Res. 43: 209-224.

, AND D. SLEZAK. 2006. Low dissolved DMSP concentrations in seawater revealed by small-volume gravity filtration and dialysis sampling. Limnol. Oceanogr. Methods 4: 80-95.

Leck, C., U. Larsson, L. E. Bagender, S. Johansson, and S. HAJdu. 1990. Dimethyl sulfide in the Baltic Sea: annual variability in relation to biological activity. J. Geophys. Res. 95: 3353-3364.

Ledyard, K. M., AND J. W. H. Dacey. 1996. Microbial cycling of DMSP and DMS in coastal and oligotrophic seawater. Limnol. Oceanogr. 41: 33-40. 
Levasseur, M., AND others. 1996. Production of DMSP and DMS during a mesocosm study of an Emiliania huxleyi bloom: Influence of bacteria and Calanus finmarchicus grazing. Mar. Biol 126: 609-618.

Malmstrom, R. R., R. P. Kiene, and D. L. Kirchman. 2004. Identification and enumeration of bacteria assimilating dimethylsulfoniopropionate (DMSP) in the North Atlantic and Gulf of Mexico. Limnol. Oceanogr. 49: 597-606.

M. Vila, And D. L. Kirchman. 2005. Dimethylsulfoniopropionate (DMSP) assimilation by Synechococcus in the Gulf of Mexico and Northwest Atlantic Ocean. Limnol. Oceanogr. 50: 1924-1931.

Mura, M. P., S. Agustí, J. Cebrian, and M. Satta. 1996. Seasonal variability of phytoplankton biomass and community composition in Blanes Bay (1992-1994). Publ. Espec. Inst. Esp. Oceanogr. 22: 23-29.

Nelson, N. B., AND D. A. Siegel. 2002. Chromophoric DOM in the open ocean, p. 547-578. In D. A. Hansell and C. A. Carlson [eds.], Biogeochemistry of marine dissolved organic matter. Academic.

Nightingale, P., P. S. Liss, and P. Schlosser. 2000. In situ evaluation of air-sea exchange parameterizations using novel conservative and volatile tracers. Global Biogeochem. Cycles 14: $373-387$.

Niki, T., M. Kunugi, And A. Otsuki. 2000. DMSP-lyase activity in five marine phytoplankton species: Its potential importance in DMS production. Mar. Biol. 136: 759-764.

Scarratt, M., G. Cantin, M. Levasseur, and S. Michaud. 2000. Particle size-fractionated kinetics of DMS production: Where does DMSP cleavage occur at the microscale? J. Sea Res. 43: 245-252.

Scarratt, M. G., M. Levasseur, S. Michaud, G. Cantin, M. Gosselin, and S. J. De Mora. 2002. Influence of phytoplankton taxonomic profile on the distribution of dimethylsulfide and dimethylsulfoniopropionate in the northwest Atlantic. Mar. Ecol. Prog. Ser. 244: 49-61.

Siegel, D. A., N. B. Maritorena, N. B. Nelson, D. A. Hansell, AND M. LoRENZI-KAYSER. 2002. Global distribution and dynamics of colored dissolved and detritial organic materials. J. Geophs. Res. 107: 3228.

Simó, R. 2001. Production of atmospheric sulfur by oceanic plankton: biogeochemical, ecological and evolutionary links. Trends Ecol. Evol. 16: 287-294.

. 2004. From cells to globe: approaching the dynamics of DMS(P) in the ocean at multiple scales. Can. J. Fish. Aquat. Sci. 5: 673-684.

, S. D. Archer, C. Pedrós-Alió, L. Gilpin, and C. E. Stelfox-Widdicombe. 2002. Coupled dynamics of dimethylsulfoniopropionate and dimethylsulfide cycling and the microbial food web in surface waters of the North Atlantic. Limnol. Oceanogr. 47: 53-61.

$\longrightarrow$, J. O. Grimalt, And J. Albaigés. 1996. Sequential method for the determination of nanomolar concentrations of dimethyl sulfoxide in natural waters. Anal. Chem. 68: $1493-1498$

—, AND — 1997. Dissolved dimethylsulphide, dimethylsulphoniopropionate and dimethylsulphoxide in western Mediterranean waters. Deep-Sea Res. II 44: 929-950.

, A. D. Hatton, G. Malin, and P. S. Liss. 1998. Particulate dimethylsulfoxide in seawater: Production by microplankton. Mar. Ecol. Prog. Ser. 167: 291-296.

- ANd C. Pedrós-Alió. 1999a. Role of vertical mixing in controlling the oceanic production of dimethyl sulphide. Nature 402: 396-399. $\longrightarrow$, AND $1999 b$. Short-term variability in the open ocean cycle of dimethylsulfide. Global Biogeochem. Cycles 13: $1173-1181$.

- , G. Malin, and J. O. Grimalt. 2000. Biological turnover of DMS, DMSP, and DMSO in contrasting open-sea waters. Mar. Ecol. Prog. Ser. 203: $1-11$.

—, AND M. VILA-Costa. 2006. Ubiquity of algal dimethylsulfoxide in the surface ocean: Geographic and temporal distribution patterns. Mar. Chem. 100: 136-146.

SlezaK, D., A. BRugger, AND G. J. Herndl. 2001. Impact of solar radiation on the biological removal of dimethylsulfoniopropionate and dimethylsulfide in marine surface waters. Aquat. Microb. Ecol. 25: 87-97.

Stefels, J. 2000. Physiological aspects of the production and conversion of DMSP in marine algae and higher plants. J. Sea Res. 43: 183-197.

—, And W. H. M. van Boekel. 1993. Production of DMS from dissolved DMSP in axenic cultures of the marine phytoplankton species Phaeocystis sp. Mar Ecol. Prog. Ser 97: 11-18.

Strom, S. L., J. L. Brainard, J. L. Holmes, and M. B. Olson. 2001. Phytoplankton blooms are strongly impacted by microzooplankton grazing in coastal North Pacific Waters. Mar. Biol 138: 355-368.

Sunda, W., D. J. Kieber, R. P. Kiene, and S. Huntsman. 2002. An antioxidant function for DMSP and DMS in marine algae. Nature 418: 317-320.

TANG, K., P. T. Visscher, AND H. DAmm. 2001. DMSP-consuming bacteria associated with the calanoid copepod Acartia tonsa (Dana). J. Exp. Mar. Biol. Ecol. 256: 185-198.

TANG, K. W., AND R. Simó. 2003. Trophic uptake and transfer of dimethylsulfoniopropionate in simple planktonic food chains. Aquat. Microb. Ecol. 31: 193-202.

Toole, D. A., D. J. Kieber, R. P. Kiene, D. A. Siegel, and N. B. Nelson. 2003. Photolysis and the dimethylsulfide (DMS) summer paradox in the Sargasso Sea. Limnol. Oceanogr. 48: 1088-1100.

— AND D. A. Siegel. 2004. Light-driven cycling of dimethylsulfide (DMS) in the Sargasso Sea: Closing the loop. Geophys. Res. Lett. 31: L09308.

, D. Slezak, R. P. Kiene, D. J. Kieber, and D. A. SiEGEL. 2006. Effects of solar radiation on dimethylsulfide cycling in the western Atlantic Ocean. Deep-Sea Res. I 53: $136-153$.

Turner, S. M., G. Malin, P. D. Nightingale, and P. S. Liss. 1996. Seasonal variation of dimethyl sulphide in the North Sea and an assessment of fluxes to the atmosphere. Mar. Chem. 54: 245-262.

Uher, G., G. Schebeske, R. G. Barlow, D. G. Cummings, R. F. C. Mantoura, S. R. Rapsomanikis, and M. O. Andreae. 2000. Distribution and air-sea exchange of dimethyl suphide at the European western continental margin. Mar. Chem. 69: 277-300.

VAllina, S., AND R. Simó. 2007. Strong relationship between DMS and the solar radiation dose over the global surface ocean. Science 315: 506-508.

van Duyl, F. C., W. W. C. Gieskes, A. J. Kop, and W. E. Lewis. 1998. Biological control of short-term variation in the concentration of DMSP and DMS during a Phaeocystis spring bloom. J. Sea Res. 40: 221-231.

Vila-Costa, M., J. Pinhassi, C. Alonso, J. Pernthaler, and R. SıMÓ. 2007. An annual cycle of dimethylsulfoniopropinatesulfur and leucine assimilating bacterioplankton in the coastal NW Mediterranean. Environ. Microbiol 9: 2451-2463. 
, R. Simó, H. Harada, J. M. Gasol, D. SlezaK, and R. P. KIENE. 2006. Dimethylsulfoniopropionate uptake by marine phytoplankton. Science 314: 652-654.

Wolfe, G. V., AND R. P. KIENE. 1993. Radioisotope and chemical inhibitor measurements of dimethyl sulfide consumption rates and kinetics in estuarine waters. Mar. Ecol. Prog. Ser. 99: 261-269.

, M. Levasseur, G. Cantin, and S. Michaud. 1999. Microbial consumption and production of dimethyl sulfide (DMS) in the Labrador Sea. Aquat. Microb. Ecol. 18: 197-205.

, AND M. STEInKE. 1996. Grazing-activated production of dimethyl sulfide (DMS) by two clones of Emiliania huxleyi. Limnol. Oceanogr. 41: 1151-1160.
Yoch, D. C. 2002. Dimethylsulfoniopropionate: Its sources, role in the marine food web, and biological degradation to dimethylsulfide. Appl. Environ. Microbiol. 68: 5804-5815.

Zubkov, M. V., B. M. Fuchs, S. D. Archer, R. P. Kiene, R. Amann, AND P. H. Burkill. 2002. Rapid turnover of dissolved DMS and DMSP by defined bacterioplankton communities in the stratified euphotic zone of the North Sea. Deep-Sea Res. Part II 49: 3017-3038.

Received: 2 January 2007

Accepted: 1 July 2007

Amended: 10 September 2007 